\title{
Implementation of Police Academy Information System in Learning Management at Police Academy Semarang
}

\author{
Tri Widada ${ }^{1}$, Achmad Slamet ${ }^{2}$, Totok Sumaryanto Florentinus ${ }^{3}$, S Martono ${ }^{4}$ \\ ${ }^{1,2,3}$ Graduate School, Universitas Negeri Semarang, Indonesia \\ ${ }^{1}$ Coresponding Email: triwidada2014@gmail.com
}

\begin{abstract}
Learning management in Police Academy Educational Institutes and Training is covers planning, implementing, evaluating and controlling. But, there are some lectures that use monotonous lecturing on the lesson plan and most of students feel less concentration about it. The aim of this study is to analyse implementation of Police Academy Information System (SIAK) in order to support learning management process. This research is done by using qualitative descriptive approach to solve it. Variables of the research are management, learning, learning management, and SIAK (Police Academy Information System). The primary data obtained from interview and observation. The secondary data obtained from through documentation. Technique analysis data is data triangulation. The results of this study have shown that the lesson plan which is composed by lectures use monotonous lecturing as learning method on the planning stages in each meeting. The conclusion is SIAK is able to use easily by the lectures and the students although they don't operate it effectively.
\end{abstract}

Keywords: Management, Learning, Learning management, SIAK

\section{Introduction}

Management according to Slamet (2007: 5) said that basically management is cooperation with people to determine, interpret and achieve organizational goals with the implementation of organizing functions; planning, organizing, actuating, and supervision (controlling).

Terry in Fattah (2013: 13) divides four main functions of management namely planning, organizing, implementation (actuating) and controlling. The approach pattern used in Institute of Education and Training of Police Academy is three patterns namely teaching, training and nurturing. The learning method is lecturing method. Actually, it decreases learners' concentration in the learning process.

According to Sagala (2009: 43), learning management can be defined as the process of managing activities, include planning, organizing, controlling and evaluating related to the process of learning by the learner to achieve the learning goals. It can be interpreted widely in the sense of covering overall activities of how to teach students ranging from learning planning to the assessment of learning.

Hermine Scheeres (2010) said that learning was fully embedded as an accepted part of necessary function of organization. It means that both the lectures and the students must consider that learning as important things to do and necessary to be held in this academy in order to give information and explanation system about police, crime, etc. .

Information system from Hanif Al-Fatta (2009:9) is a complex data which is organized with the use that is contained more than it serves. The terms states about a purpose that is going to achieve with choose and control of data and make it use.

Ahmad Assaf Alfadly (2013),stated that there are many reasons that Learning management System have failed, including cost of technology, poor decisions, competition, and the absence of appropriate (or any) business strategies especially market assessment of costumer demand. Poor decision in learning method cause the police cadet feel bored as long as learning process although they are helped by technology and information inside and outside of class. In this institution, that is difficult to achieve effective learning because the learning process conduct from 7.15 a.m. until 17.30 a.m. .

Actually, most of lectures use conventional learning method to conduct the learning process and the student feel bored about it. Beni (2009) stated that learning competence of assembly and installation of brake system with using animation media produces a better average than using conventional media. In order to solve the problem, it is needed to change the atmosphere 
of learning process. One example is using a scientific learning approach which is focused on productive courses, there are, Detective, Lantas, Binmas, Sabhara and Intel through a balanced learning process between educators with learners.

Research done by Ali Mahmudi (2015), with the title of research 'The scientific Approach in Mathematics Learning' states that the scientific approach consists of five stages or learning experience, they are observing, asking, trying/gathering an information, associating/communicating, and can be followed by creating. In order to support it, this organization uses Police Academy Information System (SIAK) which is connected to information technologies like E-Library that helps learning system and gives internet facilities such as control all of activity by CCTV.

The purpose of this research is to analyze implementation of Police Academy Information System in Learning Management at Police Academy Semarang. The benefit which is expected from this study are theoretical and practical benefit. The theoretical benefit is to produce a synthesis about implementation of Police Academy System Information inside of this institution learning management The practical benefits are the lectures can use synthesis result, this academy can use the synthesis as a thinking contribution to determine the next policy, the other education institution can use the synthesis result as references in order to enrich knowledge.

\section{Method}

The method in this research is descriptive qualitative research method with 9 informants as representative from Lectures that is teaching in Police Academy Semarang. Collect data method are interview and observation. Data analysis technique is triangulation data.

The research which seeks to describe a phenomenon, event, occurrence that recently happen is descriptive research (Asmani,2011:40). Based it, descriptive research is a study which the results are in the form of exposure to describe the circumstances or event that is happened at the same time of research ongoing and writes the truth of the situation that is happened by not adding and reducing the research result.

Bagong Suyanto (2006:172) said that research informant include three item, there are a. The key informant, are those who knows and have all of basic information which is need in the research. b. The main informant, are those who are directly involved in the social interaction under study. c. The additional informant, are those who can provide information even though they are not directly involved in the social interaction under study. In this case, the key informants are Head of education planning and controlling and Head of education administration. The main informants are the 5 lectures in 5 different courses. The additional informants are Head of education training and learning and Police Academy Information System (SIAK).

In order to collect data, researcher use interview and observation about implementation of Police Academy Information System (SIAK) in Learning Management that -yy-6include of planning, organizing, implementing and controlling. In addition, the researcher check all of document which is done by the lectures related to leaning management in this institution.

\section{Result and Discussion \\ 3.1. Learning Planning}

The results of interview with the teachers from Police Academy, they said that they have made Semester Planning Program and Lesson Plans which is related to the Institute instruction. Gradually, the leader through Sub Division of Education Planning and Control request to submit their Semester Planning Program, Syllabus, and Lesson Plans. However, from 101 courses in Police Academy, there are only 2 courses are submitted on time. It is shown that planning has been made by the lectures, but they have not implemented well. According to Stepani (2017), "The planning phase consists of the development stage of the lecture planning that includes the needs of analysis, device development and development of teaching materials". From the results of the research can be explained that it is important for teachers to analyze the learning needs for teaching and learning process, so it can run effectively and 
efficiently supported by infrastructure in developing learning materials.

According to Septyana (2013), learning planning consists of identification of training needs, learning, the determination of learning materials, the determination of method, the determination of media and the determination of learning evaluation. It can be seen that good learning planning consists of several components to achieve the learning objectives that exist in each course.

Researchers analyse documents from Semester Planning Program (RPS), Syllabus and Lesson Plans (RPP) both in Sub Division of Education Planning and Control and Compartment of lectures in each course. In those three cases, it is found that the format of some Lesson Plans are not relevant to the format of institution although Sub Division of Education Planning and Control has given the example of lesson plan format to Lectures

The first format consists of Unit of Lectures, Lesson Plans and Learning Design. One example of Unit of Lectures consists of several components: 1) Course, 2) Course Code, 3) Time, 4) Meeting, 5) Instructional Objectives, 6) Subjects, 7) Sub Subjects, 8) Teaching and learning activities, 9) Evaluation, 10) Reference.

The second Learning Design Format contains: 1) Identity of educational institutions, 2) Subjects, 3) Meetings, 4) Basic competencies, 5) Indicators of learning outcomes, 6) Highlights, 7) Time, 8) implementation of activities, 9) , 10) References.

The third format at Lesson Plan consists of: 1) Identity of educational institution, 2) Course, 3) Course code, 4) Level or semester, 5) Meeting, 6) Time allocation, 7) Course character, 8) Standard competence, 9) Main competencies, 10) Supporters competence, 11) Other competencies, 12) Indicators of achievement of competence, 13) Learning objectives, 14) Main subject, 15) Learning methods, 16) Learning steps, 17) Tools and learning resources, 18) Assessment.

Based on those three examples of lesson planning; Unit of Lectures, Learning Design and Lesson Plans as a whole, they do not have the same format but there are some components that must be written and lectures can develop the learning plan independently with basic competence.

According to Permenristekdikti No.44 of 2015 article 14 paragraph 3 states that, "Learning methods as stated in paragraph (2) that can be selected for the implementation of learning subjects include: group discussions, simulations, case studies, collaborative learning, cooperative learning, projects, problem-based learning, or other learning methods, which can effectively facilitate the achievement of graduate learning achievements." As the lectures, they must follow this Indonesian Ministry of Higher Education in order to choose a good learning method.

In lesson plan, the most common methods used are monotonous lecturing methods that are not related to the Permenristekdikti No.44 of 2015 on National Standards of Higher Education and Permendikbud. 73 of 2013 on the application of Indonesia National Curriculum Framework in the field of Higher Education where learning achievement of Indonesia National Curriculum Framework graduates is obtained through internalization of knowledge, attitudes, skills, competence and accumulated work experience during student's recovery. In this part, learners become less active and less concentration in following the learning process so that learning achievement is not achieved.

According to Widodo (2007), the process of teaching and learning using conventional methods, the students do not feel empowered in the learning process. Students are only passive because the teacher as the figure of the teaching and learning process. It is seen that Lectures must empower the students in the learning process related to the material being taught.

Based on the phenomenon, the students could not develop their ability in the learning process. In the other side, Otmar E.V. (2015), states that learning is a social event wherein learners' attributions play a key role. It means that, both the lectures and the students must interact each other in order to exchange their mind inside and outside of the class.

\subsection{Implementation of Learning}

Based on interviews with the lectures and learners, there are some lectures that use monotonous learning method. According to Purwoko (2012), lectures are not able to create a 
good atmosphere for teaching and learning process. Sometimes, some students have a bad experience; they feel bored in following the learning process ".

Furthermore, according to Widada (2017), the data of teachers of Police Academy has shown that from 231 people only 92 people who have followed the AA and Attitude and certification. The research results conclude that there is an influence on lectures competence in preparing and implementing lesson plan. In this case, learners become more active in following the learning process and not monotonous with certified Lectures.

\subsection{Supervision of Learning}

The process of supervision of learning conducted at Police Academy during this time is done as follows; Sub Division of Education Planning and Control send a letter to each compartment of course, ask the lectures to submit their Semester Planning Program and syllabus. Next, Sub Division of Education Planning and Monitoring control the contents of the syllabus. If it is not appropriate, they return it to the lectures and revise in order to reach learning purpose. In addition, Sub Division of Education Planning and Control conducts supervision in curriculum implementation that is used by the lectures. In the evaluation process, Sub Division of Education Planning and Control evaluates the syllabus and the Lesson Plans and make sure that it runs related to planning.

According to Andreas (2016), "This mentoring activity has been done well by generating a conclusion that the understanding of Biology teachers in high school, who are members of Deliberation of Subjects Teachers (MGMP) in Semarang increased as well as information and understanding of various techniques of AA assessment through discussion forum and consultation". According to Erna ( 2012), the quality of Science learning process can be improved by doing supervision of teaching with follow-up of collegial dialogical, coaching by using the instrument that has been developed related to the method of learning used by science teachers. The methods are experiment, demonstration, discussion and lecture. Both results of the study, explained that the supervision on learning method in assessment techniques can help teachers in carrying out the assessment process from the subjects taught.

The novelty of this research is the researcher discover implementation of Police Academy Information System (SIAK) in learnings management that it used by lectures and staff, although there are some of them could not use SIAK optimally. It happens because several of lectures and staffs are not able to operate information technologies.

The benefit which is expected from this study are theoretical and practical benefit. The theoretical benefit is to produce a synthesis about implementation of Police Academy System Information inside of this institution learning management The practical benefits are the lectures can use synthesis result, this academy can use the synthesis as a thinking contribution to determine the next policy, the other education institution can use the synthesis result as references in order to enrich knowledge.

\section{Conclusion}

Based on research, it can be concluded that at the planning of learning, lesson plans which have been compiled by lectures have different format but have the same components and the method used is various lecture method. In learning implementation, there is a monotonous method in the process of delivering learning materials. In learning assessment, there are two ways of assessing, practice and theory. Assessment on practice, including the grade of the teaching process, the grade of the product, the grade of practice while for the assessment of theories include the grade of the teaching process, the grade of the assignment and the grade of knowledge. In the final stage or stage of Supervision, the Sub Division of Education Planning and Monitoring has carried out its main tasks and functions, by compiling semester planning program and syllabus to control the contents of the syllabus. Supervision in curriculum implementation and evaluation of syllabus and lesson plan has been done. The use of SIAK in learning management is good although some of lectures and staffs that are not able to operate information technology. 


\section{Reference}

Achmad Slamet. 2007. Human Resource Management. Semarang: UNNES-PRESS.

Akpol. 2015. Police Academy Information System. Semarang: Akpol.

Alfadly, Ahmad Assaf (2013).The Efficiency of the 'Learning Management System (LMS)' in AOU, Kuwait, as a Communication tool in a E-Learning System. International Journal of Educational Management, Vol. 27 (2), 157-169.

Al Fatta, Hanif (2009). Analyzing and Planning Information System for Corporate Competing Excellent and Modern Organizing. Yogyakarta: Adi

Arikunto, Suharimi, 2009. Research Management. Jakarta:Rineka Cipta.

Asmani, 2011. Complete Guide to Practical Educational Research Methodology. :Jakarta,Diva Press

Bagong, Suyanto dan Sutinah. 2006. Alternative Listyawati, Erna (2012). Teaching Supervision with Collegial Dialogical Coaching Follow-Up to Improve the Quality of Science Learning Process in Junior High School. Journal of Primary Educational, Vol. 1 (1),24-30.

Harsono,Beni ,Soesanto, Samsudi (2009).The Differences In Learning Outcomes between Conventional Lectures Methods and Animated Media Assisted Lectures on Brake System Assembly and Installation Competency Learning. Jurnal PTM, Vol. 9 (4), 71-79.

Mahmudi, Ali (2015).The Scientific Approach in Mathematics Learning. National Seminar of Mathematics and Mathematics Education UNY 2015, PM-81, 561-566.

Prasetyo,Andreas Priyono Budi, Sukaesih,Sri , Hadiyanti, Lutfia Nur (2016). Assistance of Semarang City Biology Teachers in Developing Authentic Assessment Instrument on Competency-Based Curriculum. Unnes Science Education Journal, Vol. 5 (1), 1167-1175.

Permendikbud number 73 year 2013 about Implementation of Indonesian National Framework in Higher Education.
Permenristek Dikti number 44 of 2015 on National Higher Education Standards.

Purwoko,Arif. 2012.Speaking Skill Improvement through "Active Debate" in Indonesian Subjects $5^{\text {th }}$ Grade Elementary School 3 of Purwantoro, Wonogiri Regency Year 2011/2012. Education and Teacher Training Faculty. Universitas Muhammadiyah Surakarta. Surakarta

Sagala, S. 2009. Concepts and Meaning of Learning. Bandung: Alfabeta.

Septyana, Hardhike (2013).Management of Competency-Based Learning about Sewing Training in Fortuna Private Jobs Training Institutions (LPKS), Siberuk Hamlet, Siberuk Villages, Batang Regency. Journal of Non Formal Education and Community Empowerment, Vol 2 (2), 46-50.

Pamelasari, Stephani Diah , Wusqo, Indah Urwatin ,Hardianti, Risa,Dwita (2017).

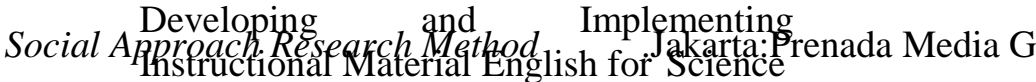
through Lesson Study. Unnes Science Education Journal, Vol. 6 (2), 1642-1647.

Scheeres, Hermine ,Solomon,Nicky , Boud,David ,Rooney,Donna (2010).When is it OK to Learn at Work? The Learning Work of Organisational Practices. Journal of Workplace Learning, Vol 22 (1/2), 13-26.

Terrry, G.R, and Rue.I.W. 2010. Principles of Management. Indonesian Edition. Translator.GA. Ticoalu. Jakarta: Earth Script.

Varela, Otmar E., Cater III, John.J, Michel,Norbert (2015).Learner-Instructor Similarity: A Social Attribution Approach to Learning. Journal of Management Development, Vol. 34 (4), 460-475.

Widada. 2017. The Influence of Lectures Competences and Job Satisfaction on Lectures Performance in Police Academy Educational Institutes and Training. Semarang: AKPOL

Widodo, Joko (2007).The Effectiveness of Using Think Pair Share Method in Economic Learning Topic of Market Price Formation in Junior High School. Jurnal Pendidikan Ekonomi, Vol 2(1), 105-122. 